\title{
EVALUASI PENILAIAN BERBASIS HOTS PADA MATA PELAJARAN BAHASA INDONESIA DI SMA LABSCHOOL KEBAYORAN
}

\section{Has'ad Rahman Attamimi | Ernawati | Hari Setiadi}

How to cite : Attamimi, Has'ad Rahman., Ernawati, \& Setiadi, Hari., 2021. EVALUASI PENILAIAN BERBASIS HOTS PADA MATA PELAJARAN BAHASA INDONESIA DI SMA LABSCHOOL KEBAYORAN. Jurnal Penelitian dan Penilaian Pendidikan. 3(1). 37- 49.

To link to this article : https://doi.org/10.22236/jppp.v3i1.5905

(C)2021. The Author(s). This open access article is distributed under a Creative Commons Attribution (CC BY-SA) 4.0 license.

\section{Published Online on 12 Desember 2020}

转 https://journal.uhamka.ac.id/index.php/jppp

View Crossmark data $₫$ 